\title{
Selection of Talented Young Players Through Volleyball Championship in The Village of Bulurejo in 2020
}

\author{
Edi Irwanto1, Bayu Septa Martaviano Triaiditya², Danang Ari Santoso ${ }^{3}$ \\ 1, 2, 3PGRI Banyuwangi University \\ Email: 1irwantoedi88@gmail.com, 2bayusepta7@gmail.com,3danangarisantoso@gmail.com, \\ doi https://doi.org/10.36526/gandrung.v1i2.937
}

\begin{abstract}
The purpose of this service is to hold a volleyball match to get young volleyball players and form a volleyball team in the village of Bulurejo in preparation for the inter-village volleyball championship at Purwoharjo sub-district level. The method used is to monitor volleyball matches between hamlets in the village of Bulurejo. The results of this activity were the talented young players and the volleyball team from the village of Bulurejo. The best players have good abilities in terms of physical conditions and basic volleyball technical skills. Where these two factors are very closed related to the ability to play volleyball a player. Because to have good basic volleyball technical skills requires good physical condition.
\end{abstract}

Keyword: Competition, Selection, Bulurejo Volleyball Team.

\section{Pendahuluan}

Olahraga adalah kegiatan-kegiatan yang bersifat fisik mengandung sifat permainan serta berisi perjuangan dengan diri sendiri dengan orang lain atau konfrontasi dengan unsur alam yang terbuka bagi seluruh lapisan masyarakat sesuai dengan kemampuan dan kesenangan. Salah satu bentuk olahraga permainan yaitu permainan bola voli (Liani, I. 2018). Permainan bolavoli adalah permainan yang di mainkan oleh dua tim yang masing-masing tim berjumlah 6 orang pemain (Mutohir, T, C, dkk. 2012). Menurut Munasifah (2010) Bolavoli adalah permainan yang dilakukan oleh dua regu, yang masingmasing terdiri dari atas enam orang. Bolavoli adalah salah satu bentuk cabang olahraga permainan bola besar, dimainkan oleh dua regu yang dipisahkan sebuah net di tengah lapangan. Seperti oahraga lainya bolavoli terdiri dari beberapa teknik dasar yang harus dikuasai yaitu servis, pasing, pukulan/smes dan bendungan.

Menururt Winarno, dkk (2013) Servis adalah sajian awal untuk memulai suatu pertandingan bolavoli, sekaligus sebagai serangan pertama bagi regu yang melakukan servis. Pasing adalah mengoperkan bola kepada teman sendiri dalam satu regu dengan suatu teknik tertentu sebagai langkah awal dalam menyusun pola serangan kepada regu lawan (Kumalasari H. 2017). Teknik Smash atau spike adalah cara memainkan bola dengan efisien dan efektif sesuai dengan peraturan permainan untuk mencapai pukulan keras yang bertujuan mematikan permainan lawan sehingga dapat menghasilkan point (Winarno, dkk. 2013). Blocking merupakan salah satu cara untuk memperlambat atau menekan 
lawan untuk mendapatkan nilai atau poin dalam sebuah pertandingan (Nopendra H.2016).

Pada awalnya bolavoli merupakan olahraga yang digunakan untuk mengisi waktu luang, kemudian berkembang menjadi olahraga yang digunakan untuk mencapai prestasi, memelihara dan meningkatkan kesehatan dan kebugaran. Oleh karena itu, diharapkan masyarakat tidak mengenal olahraga hanya sebagai penjaga kebugaran, namun juga bisa diarahkan ke olahraga prestasi. Olahraga prestasi adalah olahraga yang membina dan mengembangkan olahragawan secara terencana, berjenjang, dan berkelanjutan melalui kompetisi untuk mencapai prestasi dengan dukungan ilmu pengetahuan dan teknologi keolahragaan.

Pembinaan prestasi bolavoli pada usia muda sangat penting pada suatu cabang olahraga kususnya bolavoli karena pada usia muda perkembangan gerak sangat pesat dalam mengembangkan keterampilan dan bakat yang dimilikinya (Efendi.dkk, 2019). Untuk mencapai prestasi yang tinggi perlu adanya pembinaan dalam jangka waktu lama dan didukung atlet yang berbakat sesuai dengan keahlian cabang olahraga pilihanya, karena prestasi yang tinggi bisa dicapai dengan mudah jika cabang olahraga yang dipilihnya sesuai dengan bakatnya. Untuk medapatkan atlet yang berbakat tersebut beberapa cara dilakukan oleh pihak-pihak terkait seperti mengadakan kompetisi atau kejuaraan bolavoli mulai dari usia dini atau dari lingkup pemerintahan yang paling kecil.

\section{Metode}

\section{Sasaran}

Sasaran kegiatan ini adalah seluruh warga desa Bulurejo kecamatan Purwoharjo kabupaten Banyuwangi yang gemar bermain bolavoli.

\section{Persiapan}

Tahapan persiapan meliputi mengadakan musyawarah dengan perangkat desa Bulurejo, kemudian membentuk kepanitiaan dan tim seleksi, menentukan tempat dan jadwal pertandingan serta mengadakan sosialisasi kepada kepala Dusun.

\section{Pelaksanaan}

a. Pertandingan dilaksanakan pada tanggal 10-14 februhari 2020.

b. Bertempat di lapangan bolavoli PORDA Dusun Ngadimulyo Desa Bulurejo Kecamatan Purwoharjo.

c. Pertandingan dilakukan pada malam hari.

\section{Evaluasi}

Pada tahap ini selain didapatkan juara 1 dan 2 juga dilakukan pemilihan atau penentuan pemain 
GANDRUNG: Jurnal Pengabdian Kepada Masyarakat ISSN: 2721-6136 (Online)

muda berbakat dari keseluruhan peserta, dan pembentukan tim bolavoli desa Bulurejo.

\section{Hasil dan Diskusi}

Sebelum kejuaraan bolavoli dilaksanakan dilakukan musyawarah pebentukan tim panitia dan tim seleksi yang dipimpin oleh Bapak Kepala Desa.
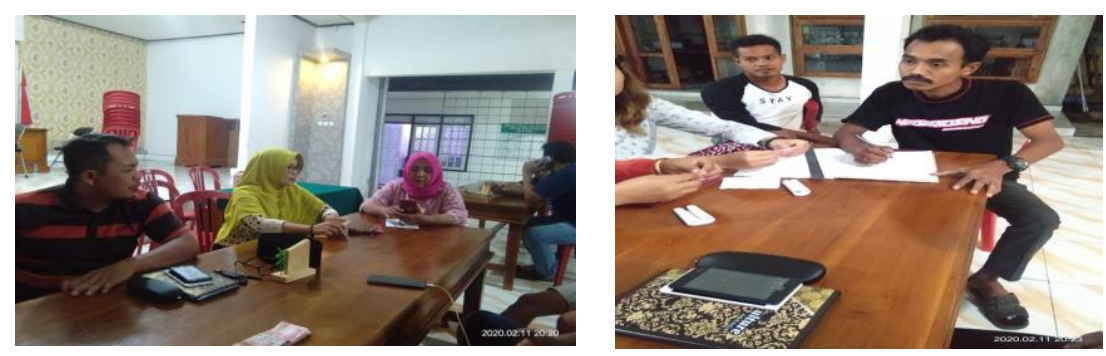

Gambar 1. Musyawarah Pembentukan Panitia

Pelaksanaan kejuaraan bolavoli antar dusun se Desa Bulurejo Kecamatan Purwoharjo Kabupaten Banyuwangi berjalan dengan lancar. Ada enam pertandingan yang terlaksana, tiga pertandingan tim putri dan tiga pertandingan tim putra.
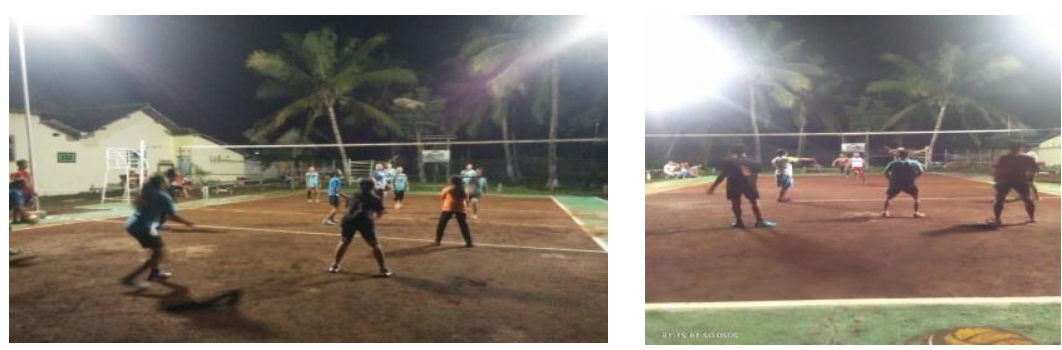

Gambar 2. Pertandingan Tim Putra dan Putri

Desa bulurejo memiliki empat dusun yaitu 1) Dusun Bulurejo, 2) Dusun Ngadirejo, 3) Dusun Ngadimulyo, 4) Dusun Tambakrejo. Jumlah peserta sebanyak enam tim (empat tim putra dan dua tim putri).Untuk juara pertama tim putri diraih tim dusun Bulurejo, dan juara dua diraih tim Dusun Ngadirejo. Untuk tim Putra juara pertama diraih tim Dusun Tambakejo dan juara dua diraih dari tim Dusun Ngadimulyo. Untuk pemain muda berbakat sesuai dengan keterampilan dan kemampuan yang ditentukan dari hasil diskusi tim didapatkan sebanyak enam pemain, empat dari tim putri dan dua dari tim putra. Secara rinci tersaji pada tebel 1 berikut:

Tabel 1. Data Hasil Kejuaraan

\begin{tabular}{lccccc}
\hline No & Dusun & Tim Putra & Tim Putri & Juara & Pemain muda berbakat \\
\hline 1 & Bulurejo & 1 & 1 & 1 Putri & Zilham dan Fifi \\
\hline
\end{tabular}


GANDRUNG: Jurnal Pengabdian Kepada Masyarakat ISSN: 2721-6136 (Online)

\begin{tabular}{lllllc}
\hline 2 & Ngadirejo & 1 & 1 & 2 Putri & Egy dan Dyah \\
\hline 3 & Ngadimulyo & 1 & 0 & 2 Putra & Vano \\
\hline 4 & Tambakrejo & 1 & 0 & 1 Putra & Gigih \\
\hline
\end{tabular}

Dari tabel diatas dapat diketahui bahwa pemain muda berbakat untuk dusun Bulurejo pemain 1 putra dan 1 putri atas nama Zilham dan Fifi, untuk dusun Ngadirejo pemain 1 putra dan 1 pemain putri atas nama Egy dan Dyah, untuk dusun Ngadimulyo pemain 1 putra atas nama Vano, dan untuk dusun tambakrejo pemain 1 putra atas nama Gigih .
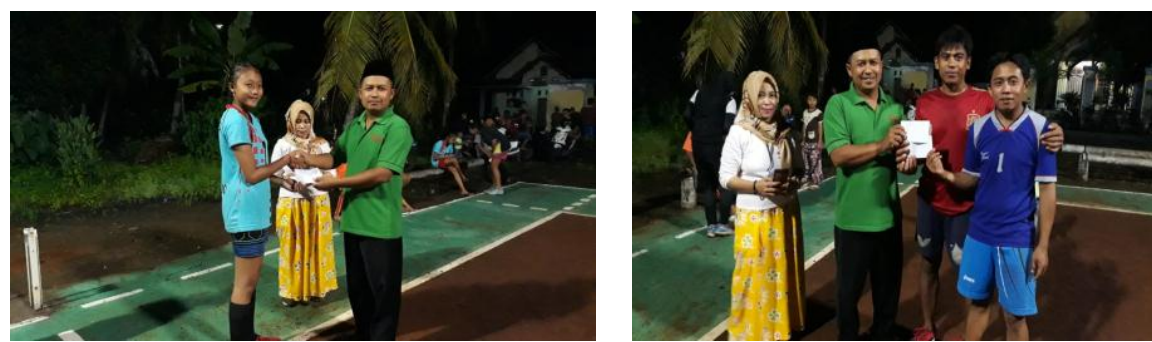

\section{Gambar 3. Pemberian Hadiah Pemain Muda Berbakat Dan Juara 1 Oleh Bapak Kepala Desa Dan Ibu Sekretaris Desa}

Selain pemain muda berbakat pada kegiatan pengabdian mayarakat ini juga Berikut nama-nama pemain tim putra dan putri yang terjaring sesuai dari hasil pengamatan dan seleksi kejuaraan bolavoli antar Dusun dan akan mewakili Desa Bulurejo pada kejuaraaan bolavoli antar desa Se Kecamatan Purwoharjo.

Tabel 2. Tim Putra dan Putri

\begin{tabular}{lcc}
\hline No & Tim Putra & Tim Putri \\
\hline 1 & Zilham & Melani \\
\hline 2 & Egy & Adistya \\
\hline 3 & Eko prastyo & Fifi \\
\hline 4 & Vano & Wulandari \\
\hline 5 & Gigih & Dita \\
\hline 6 & Vano & Hanum \\
\hline 7 & Jefry & Mela \\
\hline 8 & William & Feby \\
\hline 9 & Didik & Evira \\
\hline 10 & Andik & Gita \\
\hline
\end{tabular}

Dari tabel diatas dapat didiketahui bahwa terdapat 20 pemain putra dan putri yang terpilih sebagai tim inti bola voli desa Bulurejo. Masing-masing terdiri dari 10 untuk pemain putra dan 10 untuk pemain 
GANDRUNG: Jurnal Pengabdian Kepada Masyarakat ISSN: 2721-6136 (Online)

putri.
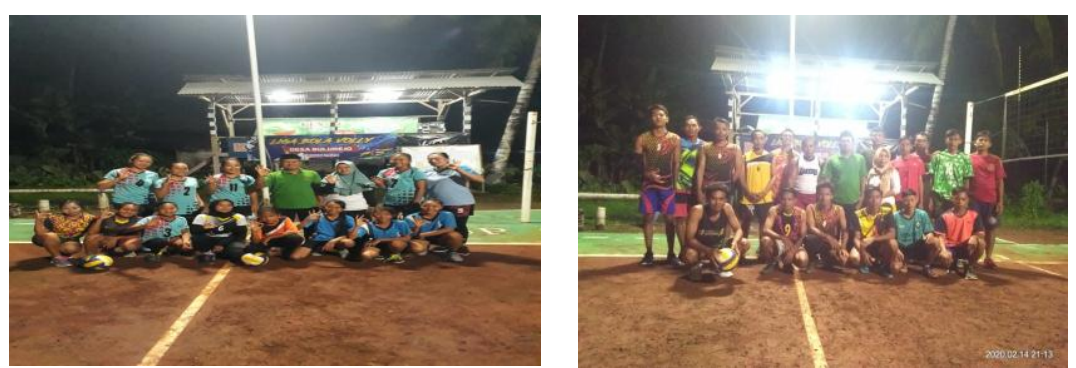

Gambar 4. Tim Putra dan Putri Desa Bulurejo

Menjadi pemain bolavoli profesianal harus mampu menguasai teknik dasar dengan baik. Beberapa teknik dasar bolavoli yang harus dikuasai yaitu servis, pasing, pukulan, dan bendungan. Dalam usaha untuk mencapai suatu keberhasilan dalam mencapai prestasi yang optimal ada beberapa faktor yang menentukan antara lain faktor Kondisi Fisik atau Tingkat kesegaran jasmani, faktor kemampuan teknik dan ketrampilan yang dimilikinya (Setyawan AR, 2011). Komponen kondisi fisik terdiri dari kekuatan, daya tahan, kecepatan, kelenturan, kelincahan dan koordinasi (Bachtiar Y, 2019).

\section{Kesimpulan}

Dari hasil pengabdian masyarakat yang sudah dilaksanakan dapat digunakan sebagai acuan perangkat Desa Bulurejo untuk menetukan tim bolavoli dengan atlet terbaik yang dapat mewakili desa Bulurejo pada kompetisi bolavoli antar Desa Se-Kecamatan Purwoharjo. Bagi atlet muda berbakat yang terpilih secara langsung menjadi bagian dari tim bolavoli Desa Bulurejo dalam kompetisi bolavoli antar Desa Se-Kecamatan Purwoharjo. Oleh sebab itu, Perlu kiranya adanya pelatihan bolavoli di tingkat dusun ataupun di tingkat desa untuk menyiapkan atlet muda yang kelak mampu bersaing ditingkat Kecamatan, Kabupaten, Provinsi dan Nasional.

\section{Daftar Referensi}

Bachtiar Y. 2019. Kondisi Fisik Peserta Ekstrakurikuler Bola Voli di SMA N 1 Pundong. Skripsi. Prodi PJKR. FIK. Universitas Negeri Yogyakarta.

Effendi, dkk. 2019. Penjaringan Atlet Melalui Kejuaraan Bola Voli Tingkat Pelajar Di Kabupaten Bengkayang. Jurnal Gervani. Vol 3 No 1:136-145

Kumalasari, H. 2017. Kemampuan Menyerang Dengan Smash Atlet Bola Voli Putri Daerah Istimewa Yogyakarta Pada Pekan Olahraga Pelajar Wilayah 2016 Di Daerah Istimewa Yogyakarta. Skripsi. Prodi Pendidikan Kepalatihan Olahraga. FIK. Universitas Negeri Yogyakarta. 
GANDRUNG: Jurnal Pengabdian Kepada Masyarakat ISSN: 2721-6136 (Online)

Liani, I. 2018. Pengaruh Latihan Merangkak Terhadap Peningkatan Kekuatan Otot Lengan Atlet Yunior Bola Voli Yuso Yogyakarta. Skripsi. Jurusan Pendidikan Kepelatihan. Fakultas IImu Keolahragaan. Universitas Negeri Yogyakarta

Munasifah. 2010. Bermain Bola Voli. CV. Semarang: Aneka IImu

Mutohir, T, C, dkk. 2012. Konsep teknik strategi dan modifikasi. Surabaya

Nopendra H. 2016. Profil Kesegaran Jasmani, Teknik Dasar Bola Voli Dan Tingkat Emotional Quotient. Skripsi. Pendidikan Kepelatihan Keolahragaan. FIK. Universitas Negeri Semarang

Setyawan AR. 2011. Pembinaan Prestasi Olahraga Bola Voli di Klub Bola Voli KMC Kabupaten Pemalang Tahun 2010. Skripsi. FIK. Jurusan IImu Keolahragaa. Unversitas Negeri Semarang.

Winarno, dkk. 2013. Teknik Dasar Bermain Bolavoli. Fakultas Olaraga Kesehatan. Universitas Negeri Malang. 